\title{
LOS BRUJOS DE VALLE-INCLÁN
}

En la obra de Valle-Inclán la palabra bruja abunda como vocativo insultante - "iCalla con esos reniegos, bruja!" (Cara, 177) ${ }^{1}$; "¡Bruja cicatera!" (Div. pal., 226) -; se integra en construcciones comparativo-descriptivas:

Las mujeres hablaban reunidas en torno de la fuente, sus rostros se espejaban temblorosos en el cristal, y su coloquio parecía tener el misterio de un cuento de brujas (Flor, 128).

...La tos del fraile, el rosmar de la vieja y el soliloquio del reloj, me parecía que guardaban un ritmo quimérico y grotesco, aprendido en la canción de alguna bruja (Son. inv., 50),

a las cuales suele agregarse un matiz desvalorativo o una intención irónico-burlona:

...Es una chimenea de piedra, que recuerda esos cuentos campesinos y grotescos de las brujas que se escurren por la gramallera abajo... (Aguila, 131).

La Galana: ...Vamos a cenar todos juntos una empanada, bajo la luna, al arrimo de un roble, como las brujas (Embruj., civ).

Sirve también para caracterizar la apariencia de un personaje, centralizar una activa alusión esperpéntica, expresar bromas, despecho, fantasías y hasta alguna advertencia no muy disimulada:

...La bruja, toda en un grito, apalea las escurridas ancas de los puercos... (Div. pal., 208).

La Bruja encaperuzó el manto sobre las sienes y voló convertida en corneja... Se anguliza como un murciélago, clavado en los picos del manto... ("Las galas del difunto", Martes, 16, 36-37).

1 Véase la explicación de las abreviaturas al final del artículo. Los números que siguen a cada abreviatura remiten a páginas. 
-Fuego no es, pero algo acontece...

Cara de Plata le dijo con burla:

-Andará alguna bruja por los tejados (Cruz., 82).

Don Farruquiño [refiriéndose al cadáver que ha puesto a hervir en la olla y cuya carne no acaba de desprenderse]: ¡Un rayo me parta si no es el cuerpo de una bruja! (Águila, 273).

... Recuerdo que algunos días en la mejilla derecha tenía [el bisabuelo] una roseola, casi una llaga: De aquella roseola la gente del pueblo murmuraba que era un beso de las brujas (Jard. umb., 161).

-iSeñor Granadero del Rey, hay que saber si son trasgos o brujas! [los que hacen moverse los huesos en una tumba] (Jard. nov., 47).

Los adjetivos derivados tienden a reducir la figura humana a una impresión, a provocar una relación pictórica o a acentuar la peculiaridad de un aspecto:

... Otra sombra negra y bruja, huye de la tribuna (Romance, 148).

...El sacristán huye por el camino de la aldea: La sotana escueta y el bonete picudo, ponen en su sombra algo de embrujado... (Div. pal., 140).

...me clavó los ojos hundidos, negros, brujos, como los tienen algunas viejas pintadas por Goya... (Son. inv., 47).

...puso en hilera las cabezas degolladas de las siete cabras: Eran de aspecto brujesco bajo el resplandor de la hoguera, con sus ojos lívidos, y sus barbas sangrientas, y sus cuernos infernales (Respl., 111).

Tampoco faltan referencias metafóricas a las prácticas mágicas en algún parlamento o algún diálogo donde se intenta explicar la de otra manera incomprensible intensidad de un afecto o señalar posibles remedios para la locura de amor:

-iOh!... ¡Cuánto te quiero! ¿Por qué te querré tanto! ¿Qué bebedizo me habrás dado? (Son. inv., 97) .

Sabelita: ¡Loco!

Cara de Plata: Pónme tú cuerdo.

Sabelita: ¿Con qué yerbas?

Cara de Plata: Con palabras (Cara, 31).

Esta variada abundancia en el aspecto estilístico se corresponde en diversas páginas con la pululación de brujos, resultado en gran medida de la importancia concedida al Diablo, y que parecería probar el aserto de Grillot de Givry acerca de la realidad española: "España empezó a ser tierra de brujos hace muchísimo tiempo y todavía lo es hoy" (GRILlot, 68). 
A lo largo de la historia, la actitud de la Iglesia no desmiente la afirmación, pues para ella los brujos fueron herejes ${ }^{2}$ y a veces competidores de los miembros del clero ("... al lado de los sacerdotes de la religión oficial, ejercían el ministerio de conjurar, y eran tan solicitados como aquéllos, los practicantes de las viejas fórmulas no cristianas, como los saludadores": CARo, Mitos, 222), sin que faltara de cuando en cuando algún ejemplo en contrario, pues por lo menos en Galicia y en el siglo Xvi "la mayor parte de los considerados brujos eran sacerdotes", hasta el punto de que "el canon LIX del segundo Concilio de Braga" tuvo que prohibir "a los clérigos ser encantadores o hacer ligaduras" (Rodríguez, 47).

La Inquisición, que funcionó en España desde el siglo XIII, persiguió tanto a los brujos como sus prácticas (Rodríguez, 42), y, tardíamente establecida en Galicia (1562), provocó allí más daño económico - a causa, sobre todo, de arbitrariedades contra barcos mercantes extranjeros- que mella directa en la población, pues, a pesar de las arraigadas supersticiones y no escasas actividades, el número de víctimas es sorprendentemente bajo (ibid., 44).

Quizá por esto, cuando Valle se refiere a las intervenciones del Santo Oficio y a los castigos impuestos a los reos de brujería, su tono más que a ataque encarnizado suena a burla y su intención parece dirigida a buscar situaciones cómicas o caricaturescas.

En Sonata de primavera (190-191, 207-209) se apunta a la escasa validez de una acusación como la de Polonio, en quien contrasta el miedo a los efectos de las prácticas hechiceriles y lo que ha intentado contra Bradomín; la acusación, sin embargo, será acogida con beneplácito por el Santo Oficio. La situación así creada sirve también para mostrar la cándida bondad de María Rosario frente a la cortesana habilidad del Marqués, brujo quizá, aunque no del tipo habitualmente condenado.

En La Marquesa Rosalinda se busca un marco verbal apropiado al despecho amoroso de Colombina contra la mujer que le roba a Arlequín y en el cual proyecta simultáneamente el concepto que de ella tiene -bruja suministradora de bebedizos- y el deseo de verla ejemplarmente castigada (Marquesa, 157):

¡Viérala a los lomos de un rucio aceitero, con la caperuza y con la coroza, entre los pregones que hace el pregonero!

2 A comienzos del siglo xvi, el Inquisidor mayor Alonso Manrique promulgó un edicto según el cual era deber de todo católico denunciar a quienes acogieran familiares y espíritus, practicaran cualquier sistema de adivinación o trazaran círculos para conjurar demonios, emplearan la astrología para predecir la suerte y poseyeran espejos o anillos para aprisionar espíritus y grimorios o cualesquier otros libros de magia. La bula de Sixto V (1585) condenó como heréticas todas las formas de adivinación y encantamiento, el pretendido con- 
Dos entrecortados diálogos de Los cuernos de Don Friolera (76, 87-88) expresan el choque entre el Teniente y la Beata, y caracterizan el maligno entrometimiento de Doña Tadea mencionando la pena capital aplicada a las brujas:

Don Friolera: Doña Tadea, merece usted morir quemada.

Doña Tadea: ¡Está usted loco!!

Don Friolera: iQuemada por bruja!

Don Friolera: ¡El honor se lava con sangre!

Doña Tadea: ¡Eso decían antaño!...

Don Friolera: ;Cuando quemaban a las brujas!

En "Las galas del difunto" (Martes, 33), la rabia en aumento del Boticario convertirá verbalmente a la Bruja en diablo volador y luego en objeto del castigo que merecían las actividades de las terceras, tantas veces asociadas con la hechicería ${ }^{3}$ :

El Boticario: ...¡llévate ese papel y remonta el vuelo, si no quieres que te queme las pezuñas!...

La Bruja: ¡Iscariote!

El Boticario: ¡Emplumada!,

castigo que siglos antes había encontrado eco por razones semejantes en dos pasajes de La Celestina ${ }^{4}$ :

Pármeno: ...E lo que 'más dello siento es venir a manos de aquella trotaconventos, después de tres veces emplumada.

Sempronio: Madre, mira bien lo que haces..., no vayas por lana e vengas sin pluma.

Celestina: ¿Sin pluma, fijo?

Sempronio: O emplumada, madre, que es peor,

y en dos textos de Quevedo: el epitafio dedicado al personaje de Rojas y el retrato de la madre del Buscón:

trol de demonios y toda clase de hechizos, magia y supersticiones. La Inquisición española conservó su convicción en la realidad de los procedimientos mágicos hasta entrado el siglo xix (Robins, 475) .

3 Cf. también: "Yerba del Hombre de la Montaña. [Hassan Sabbah, emir de la secta mahometana de los Asesinos], / El Santo Oficio te halló en España. // Cáñamos verdes son alumbrados, / Monjas que vuelan, y excomulgados. // Son ciencia negra de la Caldea / Con que embrujada fue Melibea" ("La tienda del herbolario", Pipa, 140).

4 Fernando de Rojas, La Celestina, ed. Clás. cast., 1963, t. 1, pp. 121 y 140. La p. 121 trae una nota con un texto aclaratorio de Quevedo: "Untábale el verdugo, desnudándole de medio cuerpo arriba, con miel al alcahuete, y le cubría de pluma menuda, sacándole así a la afrenta pública". 
Yace en esta tierra fría, digna de toda crianza, la vieja cuya alabanza tantas plumas merecía ${ }^{5}$.

...Un día, alabándomela una vieja..., decía que era tal su agrado, que hechizaba a todos cuantos la trataban; sólo diz que le dijo no sé qué de un cabrón, lo cual la puso cerca de que le diesen plumas con que lo hiciese en público... Unos la llamaban zurcidora de gustos; otros algebrista de voluntades desconcertadas, y por mal nombre alcagüeta ${ }^{\circ}$.

En un último ejemplo, Valle esperpentiza una cigüeña humanizándola por medio de una comparación (Pipa, 45-46) :

Sobre una pata se arrebuja,

$Y$ en el tejado hace oración,

Como una bruja

Que escapó a la Inquisición,

lo cual sugiere dos interpretaciones: el agradecimiento - đa quién?de alguien que ha conseguido hurtar el cuerpo al Santo Oficio, o una plegaria en incomodísima posición impuesta como castigo en lugar de la pena máxima.

\section{EL CONCEPTO}

El concepto que Valle-Inclán tiene de los brujos no se sujeta a ninguna definición precisa, sino que las funde todas. Encontramos así la posibilidad de que sean de uno $u$ otro sexo (Thomas, 436) : hombres, como el estudiante de "Mi hermana Antonia" y el saludador de Flor de santidad ${ }^{\top}$, o mujeres, como la poderosa saludadora de Céltigos, alguna vez aludida y otra presentada con los rasgos más clásicos:

A media noche llegó la Saludadora de Céltigos... Entró salmodiando saludos y oraciones. Era vieja, muy vieja; con el rostro desgastado... y los ojos verdes, del verde maléfico que tienen las fuentes abandonadas, donde se reúnen las brujas ("Beatriz", Hist., 78-79),

5 Francisco de Quevedo, “A Celestina”, Obras completas. Verso, Madrid, 1952, p. $99 a$.

- Francisco de Quevedo, Historia de la vida del buscón llamado Don Pablos, libro I, cap, 1, en Obras completas. Prosa, Madrid, 1958, p. $288 a$.

7 Flor, 60; cf. también: “... a las barbas blancas pedirás consejo / si tienes ovejas con alferecía" (Voces, 21). 
cuyas dotes vemos ejercitarse para el mal tanto en "Beatriz" como en $A$ guila de blasón y que contrasta con la belleza misteriosamente atractiva de la joven y temible Rosa Galans, especie de Circe campesina. Todos buscan controlar la naturaleza y producir, según el caso, efectos benéficos o malignos (Robbins, 47lab; Caro, Milos, 224, 225, 253; Thomas, 436-437), para lo cual se valen en general de hechicerías y ensalmos (Thomas, 436-437, 463), no faltando quien recurra a la ayuda del mismo Demonio (RobBins, 47lab) :

La Condesa salió y trajo el breviario de Fray Ángel. La Saludadora arrancó siete hojas y las puso sobre el espejo. Después, con las manos juntas como para un rezo, salmodió:

-¡Satanás! ¡Satanás! Te conjuro por mis malos pensamientos, por mis malas obras, por todos mis pecados. Te conjuro por el aliento de la culebra, por la ponzoña de los alacranes, por el ojo de la salamantiga. Te conjuro para que vengas sin tardanza y en la gravedad de aqueste círculo del rey Salomón y en él te estés sin un momento de partir, hasta poder llevarte a las cárceles tristes y oscuras del infierno el alma que en este espejo ahora vieres. Te conjuro por este rosario que yo sé profanado por ti y mordido en cada cuenta. ¡Satanás! ¡Satanás! Una y otra vez de conjuro ("Beatriz", Hist., 81).

La de Céltigos posee además facultades fisiopsicológicas espontáneas ${ }^{8}$ :

- ¿Pero no vio a un fraile?

-A nadie, mi señorạ.

- Q Quién le llevó el aviso?

- No fue persona de este mundo. Ayer de tarde quedéme dormida, y en el sueño tuve una revelación. Me llamaba la buena Condesa moviendo su pañuelo blanco, que era después una paloma, volando, volando por el cielo (Hist., 79).

Casi todos pueden influir en la mente humana y producir odio, amor, simples ilusiones o franca locura (Hole, 17; Lethbridge, 14); pero ejercen su poder especialmente en lo que concierne a la fertilidad (Hole, 54), continuando así lo señalado siglos antes por la bula de Inocencio VIII (9 de diciembre de 1484) : “...por sus encantos, hechizos, conjuros, sortilegios, crímenes y actos infames, destruyen y matan el fruto en el vientre de las mujeres..., impiden que los hombres puedan engendrar y las mujeres concebir..." (CAro, Brujas, 141). Por todo esto, la Pichona supone que la repen-

8 Thomas, 463. De manera parecida se explica la capacidad de leer el futuro: "...certain favored people in every generation possess a peculiar metabolism that enables them to see into the future as they see the things around them" (SybIL LeEck, The Sybil Leek Book of fortune telling, The Macmillan Co., 1969, p. 11). 
tina frialdad de Cara de Plata para con ella se debe a mal de ojo provocado por alguna bruja (Aguila, 249) ; la mujer sometida a $\mathrm{Mi}$ lón de Arnoya ${ }^{9}$ por una pasión irrefrenable y culpable la achaca a hechizo y presenta muchos de los síntomas de posesión debida a embrujo, tan similares a los de la demoníaca (RobBins, 335a); la moza del ciego piensa que el hombre dominado y enloquecido por Rosa Galans sólo se curará recibiendo las ondas del mar a media noche, como los posesos (Embruj., xcIx) ; y por esto, también, la mujer del mayordomo, en Los cruzados de la causa, podrá atribuir su esterilidad a maleficio y tratar de contrarrestarlo con una higa de azabache (Cruz., 52-53). Y si en los casos anteriores las brujas han tenido por lo menos un éxito de sugestión, tampoco falta en la lista una impostora, a quien sólo desenmascara un español nacido en Galicia (Son. prim., 169).

\section{MAGIA NEGRA}

Valle-Inclán ilustra en su obra casi todos los maleficios que, según Nider (1435), podían causar los brujos (RobBins, 331a): 1) inspirar amor, de lo cual se jacta la hechicera italiana; 2) inspirar odio; 3) provocar impotencia, poder que también se atribuye la bruja de Sonata de primavera; 4) provocar enfermedad, como Máximo Bretal; 5) quitar la vida, como la saludadora de Céltigos; 6) privar de la razón, como Rosa Galans en El embrujado; 7) dañar la propiedad o los animales, de lo cual es causa la maldición del falso peregrino en Flor de santidad. En todos estos casos, y en algunos otros, prácticamente nadie duda ni por un momento de que la desgracia acaecida se deba a una misteriosa actividad humana (TroMAS, 436), y el empeño de los brujos se apoya sólidamente en la "fe" de las víctimas (Hole, 18).

La mayoría de los efectos, sin embargo, recibe el nombre general y popular de mal de ojo, el cual, lo mismo que en Italia, designa en conjunto la hechicería hostil (LELAND, 170) y ha sido temido por los hombres desde la remota antigüedad (LAwson, 15). Reconocido por Santo Tomás de Aquino (1225-1274) (RobBins, 29a) y registrado por Martín del Río (1599) (ibid., 194b) con el nombre más culto de fascinación, resultaría de un invisible pero potente efluvio de los ojos de los brujos (Thомas, 437), aunque no sea exclusivo de ellos y en ocasiones incluso determine autodaños (LAwson, 9, 10; Thomas, 464). Universal creencia entre el campesinado, de ninguna manera es extraño a clases supuestamente más cultas, si

9 "Milón de Arnoya", Los Lunes de "El Imparcial", Madrid, 22 de junio de 1914, p. 3; Jard. umb., 195-202. 
bien no lo confiesan con la franqueza de aquél (Thomas, 9) ${ }^{10}$, y en Galicia su influjo también es general (Rodríguez, 149-155).

En las obras de ambiente rústico, o cuando hace hablar a personajes de poca educación, Valle-Inclán lo refiere sea a una repentina $e$ inexplicable enfermedad del ganado ${ }^{11}$ :

...Las ovejas iban saliendo una a una, y la ventera las contaba en voz baja. La última cayó muerta en el umbral..., la ventera exclamó: -jAy!... De por fuerza hiciéronle mal de ojo al ganado... (Flor, 51-52; cf. también 71 y 72);

sea a las manifestaciones de una pasión en que el deseo y el temor se confunden, como en el caso de Anxelo (Embruj., xcix); sea a resultados de lo que no se sabe si es capricho o romanticismo juvenil (Enam., 15) :

La Ventera: ¡Ser dama de reyes! ¿No te da sonrojo?

¿Guidado la niña! ¡Te hicieron mal de ojo!;

sea asimilado a la mala sombra, con la cual algo tiene en común:

-...Le acompaña a ese hombre un sino muy negro... ¿Recuerdas cuando le vimos en la feria? Pues con solamente verle, me ha hecho mal de ojo. Esta zaragata del espanto y la otra de la plaza te lo confirman (Viva, 437).

De vez en cuando alguíen se permite poner en tela de juicio su existencia, quizá en un despliegue jactancioso de sólida razón, así el Mayor del Valle: "- ¿El mal de ojo? No creo en ello" (Tirano, 100). Lo normal, sin embargo, es que lo acepten incluso aquellos en quienes una mayor delicadeza de espíritu lo haría más o menos impensable; tal es el caso de Feliche Bonifaz, con cuyo terror ante la maligna mirada de la molinera, por considerarlo agüero de un destino nefasto, Valle estaba quizá anticipándonos en parte algo que pensaba escribir acerca de las relaciones entre Bradomín y la hermana del Pollo Real (Corte, 168-170):

...El susto de su voz se intercalaba con el parlamento de la Marquesa: -jAquella mujer hacía mal de ojo! (ibid., 281).

10 Véanse también Spence, 156, y Caro, Mitos, 264 ss. En ocasiones parece significar lo mismo que "echar una mala fada" (Flor, 114; Embruj., LxxII).

11 Cf. Thomas, 538: "...the more unusual occurrence might still be attributed to witchcraft - the epidemic which spread through one farmer's herd, but did not affect those of his neighbors". De la lista de preguntas obligatorias utilizada por los jueces de Colmar (Alsacia) para interrogar a los brujos, interesa aquí la número 21: "¿Qué animales ha hechizado usted hasta el punto de enfermarlos o matarlos, y por qué cometió usted tales actos?" (RosBins, 107a). 
De otra manera funciona cuando Valle intenta una burla o se propone esperpentizar. La ilustrada Marquesa Rosalinda, al criticar los celos de su marido y la superstición española, deja también traslucir vehementemente su propia actitud mental (Marquesa, 142) :

Rosalinda: ...A mi marido

Le entró un furor sangriento que nunca había tenido. ¡No sé qué mal de ojo le hicieron en España!

Y sirve de contraste ridículo unido a otro cargo junto con el cual ha contribuido a la prisión de dos personajes (Cuernos, 261) :

...Don Manolito y Don Estrafalario... son huéspedes de la trena, por sospechosos de poner bombas y haber hecho mal de ojo a un burro en la Alpujarra.

En estrecha relación con el mal de ojo, que es sólo una forma de sugestión de una mente más enérgica sobre otra más débil o atemorizada, están los casos evidentes de hipnotismo, sin duda ejercido en sus víctimas por los brujos de mayor experiencia (HoLE, 123; véase también GRILLOT, 325), reconocido por Avicena (980-1037) a través de un párrafo que parece fundir ambos conceptos ("...el alma de ciertas personas puede influir en el cuerpo de otros, por su virtud y fuerza natural para trastornarlo y cambiar el sentido de las personas y fascinar los ojos...": Rodrícuez, 40), y considerado por los ocultistas uno de los recursos de la magia negra (Blavatsky, 147). Valle, quien sentía gran interés por el hipnotismo desde muchos años atrás ("Psiquismo", Public., 214-215), suele echar mano de él. Fuerza magnética es la que experimenta sobre sí el niño en "Del misterio":

...Yo estaba medio dormido en el regazo de mi madre, y sentí el peso magnético de sus ojos que me miraban. Mi madre también debió advertir el maleficio de aquellas pupilas que tenían el venenoso color de las turquesas (Jard. not,, 189);

y la que, siguiendo acaso un procedimiento aconsejado a los brujos de todas las edades -obligar a la mujer deseada a mirarlos al fondo de los ojos (Haining, 56) -, pone en práctica Máximo Bretal ("Mi hermana Antonia", Cofre, 105-106) :

Antonia murmuró blanca como una flor:

-Déjeme usted, Don Máximo.

-No te dejo. Tú eres mía, tu alma es mía... Mírame, que tus ojos se confiesen con los míos. ¡Mírame!,

con lo cual se explica tan bien el aspecto de Antonia páginas después (ibid., 119): “...Antonia abrió el balcón y miró a la plaza 
con ojos de sonámbula. Se retiró andando hacia atrás, y luego escapó". Fuerza magnética es igualmente la que permite a Rosa Galans esclavizar a Anxelo (Embruj., LxxIII-LxxIv):

...jRosa Galans vendrá por mí!... Mauriña, vamos para adentro de la casa, cierra la puerta. ¡No la dejes entrar, que si me mira he de irme con ella!,

y a unos vagabundos, lograr que los perros no denuncien su fuga (Cruz., 218):

- ¿Cómo no ladrarían los perros? callar.

-Esa gente que anda por los caminos, tiene mañas para los hacer

-Parece, talmente, que con los ojos los encantan.

No sorprende, pues, la pregunta desconfiada de Lupita la Romántica al Doctor Polaco cuando éste la incita "al estudio de los iniciados en los misterios del magnetismo" (Tirano, 114):

$-¿$ No es usted brujo?

-El estudio de los fenómenos magnéticos no puede ser calificado de brujería (ibid., 115).

Aunque no con frecuencia, los maleficios se identifican más precisamente. Uno de ellos, que proporciona el título a un breve esperpento teatral -la ligazón amatoria que une física y criminalmente al Afilador y la Mozuela ("Ligazón", Retablo, especialmente 50-53) ${ }^{12}-$, vuelve a aludirse en el diálogo entre Pichona la Bisbisera y la voz del Fuso Negro, señalando por una parte la relación entre ella y Cara de Plata, y, por otra, la forma de eliminarla, la cual no es un rasgo grotesco más sino que apunta a ingredientes usados en brujería (Haining, 63) :

Pichona la Bisbisera: Me tiene ligada.

La voz de la chimenea: Si en la cama te meas, quiebra el lazo (Cara, 256).

Otro maleficio, ejemplo de condenación, ilustra también el sortilegio que para realizarse echa mano de objetos de uso religioso -el breviario en el texto que ofrecemos a continuación y el rosario durante el conjuro páginas después-, lo cual constituye una de las más perversas y heréticas manifestaciones de las prácticas de los brujos (Hole, 157; Robbins, 472b) :

12 Caro, Brujas, 143, indica, sin explicar, que el Malleus maleficarum hace referencia a diversas clases de ligazones amatorias. 
- ¿Sabe hacer condenaciones?

- iAy, señora mi Condesa, es muy grande pecado! nará...

- ¿Sabe hacerlas? Yo mandaré decir misas y Dios se lo perdo-

-Sé hacerlas, mi Condesa.

-Pues hágalas...

- ¿A quién, mi señora?

-Al capellán de mi casa...

-Para eso hace menester del breviario ("Beatriz", Hist., 80),

situación donde encontramos, además, la profanación evidente de las misas, cuya intención se pretende aplicar a un fin en decidido contraste con el sufrimiento que la madre de Beatriz aseguraba haber padecido viéndola aborrecer "de todas las cosas santas" (ibid., 73), amén del convencimiento presuntuoso y nada cristiano de que con ellas se obligará a la Divinidad.

De los varios medios utilizados por los brujos para realizar sus propósitos, Valle-Inclán destaca cinco. El primero es la imagen de cera que deberá imposibilitar a Bradomín para continuar sus aventuras donjuanescas:

$-¿ Y$ vos qué intentabais hacer?

-Ya antes os lo dije... Me mandaban privaros de toda vuestra fuerza viril... Hubierais quedado como un niño acabado de nacer...

- ¿Cómo obraríais ese prodigio?...

Siguió revolviendo en la ceniza y descubrió una figura de cera toda desnuda, acostada en el fondo del brasero. Aquel ídolo, esculpido sin duda por el mayordomo, tenía una grotesca semejanza conmigo. Mirándole, yo reía largamente, mientras la bruja rezongaba.

- Ahora os burláis! ¡Desgraciado de vos si hubiese bañado esa figura en sangre de mujer, según mi ciencia...! ¡Y más desgraciado cuando la hubiese fundido en las brasas!... (Son. prim., 174-175) .

En éste quizá el procedimiento más conocido y criminal de la magia imitativa, cuyo lazo de unión con la víctima es la imagen que la representa y la cual, en su carácter de réplica, se somete a toda clase de malos tratos que terminarán por afectar al destinatario (Hol.E. 17; Cavendish, 20; Lawson, 17). Para completar su labor maléfica, la bruja ha hecho robar un anillo con una amatista, pues necesitaba una piedra usada por el Marqués durante muchos años (Son. prim., 174), es decir, algo que hubiera estado en contacto estrecho con su cuerpo y que por esto mantuviera la relación con él después de separado $^{13}$. Lo que solicita la saludadora de Céltigos para romper la

13 Cavendish, 19: "Another kind of link is provided by the magical law that anything which has once been part of a man's body or in close contact with him retain its connection with his body even after it has been physically separated from him". 
atracción entre Sabelita y Don Juan Manuel se asemeja bastante (Aguila, 300-301) :

Liberata: ...De por fuerza le ha dado algún hechizo para tener así cautivo su corazón.

La Manchada: Contra hechizos hay hechizos, y si una bruja sabe mucho, dos saben más.

Rosalva: Los hechizos se rompen.

La Manchada: ¿Por qué no ves a la Saludadora de Céltigos? Ésa sabe de conjuro y tiene remedios para congojas de amores.

Liberata: Ya la he visto... Díjome que si hay hechizo, para romperlo precisaba una prenda que hubiese llevado mucho tiempo Doña Sabelita... ¿ ¿Vosotras no podríais darme esa prenda?

Rosalva: Yo guardo un pañuelo bordado, regalo suyo. Te lo daría, pero temo que le venga algún mal... iCuéntanse tales cosas de la vieja de Céltigos!...

Rosalva termina por entregar el pañuelo, y la Manchada se lo reprocha (ibid., 302-303). Los temores de las dos mujeres contribuyen a acentuar la impresión del lector, ya despierta por el presentimiento de otros personajes y por el indudable proceso psicológico de Sabelita.

El tercer instrumento es la manzana, que por el hecho de ser una clase de comida goza de la preferencia de los brujos en la realización de sus peores propósitos (Leland, 207) ${ }^{14}$. En la obra de Valle funciona para encadenar la voluntad de una mujer, tal como la empleaban muchos brujos en provecho propio ${ }^{15}$ :

Vino una vieja... y trajo de regalo un azafate de manzanas reinetas. En una de aquellas manzanas dijeron después que debía estar el hechizo que hechizó a mi hermana Antonia (Cofre, 102).

-...cuando estaba buscando amo caí con el alma en el cautiverio de Satanás. Fue un embrujo que me hicieron en una manzana reineta ("Milón de Arnoya", Jard. umb., 196).

y también para privar a una madre en espera del hijo en gestación:

La Preñada: Una mala mujer dióme un hechizo en una manzana reineta, y no logro familia (Aguila, 204).

En cuanto a su valor simbólico, consiste en haber sido el fruto con que se tentó a nuestros primeros padres; pero su valor "real" reside en ofrecer inmejorable escondrijo al demonio (Robsins, 393a).

14 Recuérdese el membrillo hechizado que una dama desdeñada ofrece, por consejo de una morisca, a Tomás Rodaja en El licenciado Vidriera.

15 Haining, 55: "The more subtle warlock could achieve his desires still more simply by pressing upon the desired girl an apple", y sigue una indicación de lo que debe escribirse sobre ella y la fórmula que debe pronunciarse para lograr el efecto apetecido. 
La polifacética medium en "Del misterio" emplea el espejo en prácticas necrománticas, dilectas de los brujos (Jard. nov., 188) .

...Aquella señora me infundía un vago terror, porque contaba que en el silencio de las altas horas oía el vuelo de las almas que se van, y que evocaba en el fondo de los espejos los rostros lívidos que miran con ojos agónicos ${ }^{16}$.

En "Beatriz", la saludadora lo utiliza para descubrir un maleficio:

-A esta rosa galana le han hecho mal de ojo. En un espejo puede verse si a la mano lo tiene mi señora.

La condesa le entregó un espejo guarnecido de plata antigua. Levantólo en alto la Saludadora, igual que hace el sacerdote con la hostia consagrada, lo empañó echándole el aliento, y con un dedo tembloroso trazó el círculo del rey Salomón. Hasta que se borró por completo tuvo los ojos fijos en el cristal:

-La Condesita está embrujada. Para ser roto el embrujo han de decirse las doce palabras que tiene la oración del Beato Electus al dar las doce campanadas del medio día, que es cuando el Padre Santo se sienta a la mesa y bendice a toda la cristiandad (Hist., 80);

pero el mismo instrumento sirve para reflejar el rostro de un culpable todavía vivo ${ }^{17}$ y a quien se desea destruir (Hist., 81). Lo cual demuestra, por una parte, el concepto de Guazzo (1608) de que la magia blanca puede convertirse en nociva e ilegal si se aplica a un fin perverso que ponga en peligro, con ayuda diabólica, los cuerpos y las almas (RobBins, 540b), y, por otra parte, la malicia de los brujos al emplear magia blanca o magia negra según lo requieran los casos (Hole, 131).

De la misma naturaleza que el maleficio, aunque no se sujete a una determinada fórmula ${ }^{18} \mathrm{y}$ de acuerdo con lo que se supone desde hace siglos, la maldición puede herir con el enunciado de sus palabras hostiles (Thomas, 502) y se espera de ella que alcance deliberadamente el blanco propuesto (Lawson, 388). Este quinto instrumento consta de dos partes fundamentales: la formulación del deseo de que un daño se produzca, damnum minatum cuya fuerza

16 En "La rosa del reloj", Clave IV de $E l$ pasajero, vuelve a insistirse en este aspecto de las actividades de las brujas, pero sin referencia a espejo alguno: "Es la hora del alma en pena: / Una bruja en la encrucijada, / Con la oración excomulgada / Le pide al muerto su cadena. / ¡Es la hora del alma en pena!" (Pasaj., 77) .

17 Thomas, 215: “. . others... used mirrors or crystal balls in which the client would be asked if he could perceive the features of the guilty party" (véase también 549).

18 Spence, 378a; Justine Glass, They foresaw the future, G. P. Putnam's Sons, New York, 1969, 170-187. 
más profunda e intensa conoce bien la bruja de "Las galas del difunto" (Martes, 15):

La Daifa: ¡No habrá una peste negra que se lo lleve!

La Bruja: Tú llámale por la muerte, que mucho puede el deseo...,

y el cumplimiento consiguiente o malum secutum (RoBsins, 331a). Es exactamente lo que encontramos en Flor de santidad, donde el peregrino, irritado por la falta de caridad de la dueña de la venta -falta que por sí misma favorece la realización de un daño ${ }^{19}-$, maldice la casa:

...De pronto, volvióse, y rastreando un puñado de tierra lo arrojó a la venta. Erguido en medio del sendero, con la voz apasionada y sorda de los anatemas, clamó:

-iPermita Dios que una peste cierre para siempre esta casa sin caridad! (Flor, 32).

Poco tiempo después se inicia la misteriosa enfermedad que arrebata una a una las ovejas, provocando el despecho del hijo de la ventera, quien terminará por asesinar al peregrino; esto, sumado a otros crímenes cometidos en la casa y acerca de los cuales la gente murmura:

...Los pastores referían historias que ponían miedo en el alma de la niña: Eran historias de caminantes que se hospedaban en la venta y desaparecían... y 'de muertos que amanecían en los caminos (Flor, 81),

determina su arresto y, muy posiblemente, la clausura de la mal afamada casa.

\section{Magia BLANCA}

Mientras la finalidad de la magia negra y de quienes la practican es perjudicar, la magia blanca pretende causar beneficios, entre los

19 Según Bodin, la caridad era la mejor protección porque las brujas no podian dañar al hombre caritativo aun cuando tuviera otros defectos (RoBbins, 88b). F. Trigge (A Godly and Fruitfull Sermon, Oxford, 1594, f. 4v) opina que las brujas no pueden dañar a quienes son caritativos con los pobres, y que la mejor salvaguardia cristiana contra la brujería es ser generoso (Tномаs, 564). En la misma obra encontramos además que muy característicamente las supuestas víctimas de una bruja habian faltado a sus obligaciones negándole limosna (555) y que la mayoría de las acusaciones informales registradas durante los siglos xvin, xIx y $\mathbf{x x}$ se ajustan al mismo patrón: caridad eludida seguida de desgracia (582). 
cuales figura muy particularmente el contrarrestar los efectos de la primera. Tales son las tareas del saludador, séptimo hijo varón en una línea exclusivamente masculina y de quien se cree "tiene una cruz en el cielo de la boca o debajo de la lengua", y su saliva, virtud de curar (Rodríguez, 117). Sus actividades coinciden en general con las de todos los brujos blancos, cuyo retrato ideal ofrece Christina Hole:

El brujo blanco... era el protector de la comunidad..., se atenía a la magia, pero la aplicaba sobre todo a propósitos benéficos: curar enfermedades, anular sortilegios, descubrir ladrones y encontrar bienes robados... Su influencia fue muy grande, y no se ha extinguido por completo... Cuando no abundaban los médicos y su experiencia era escasa, podía a menudo curar dolencias sencillas por medio de hierbas y sentido común, guarnecidos con ensalmos. Era el depositario natural del saber campesino, que no siempre fue tan disparatado como se tiende a creer hoy. Poseía cierta familiaridad con la psicología práctica y con las hierbas medicinales, e incluso solía tener conocimientos médicos y veterinarios extremadamente útiles en las aldeas aisladas (HoLE, 129).

Que muchas veces no fueron tan diestros, atinados y veraces lo prueban las reacciones no sólo de la Iglesia ("...los prelados reunidos en el concilio de Tours el año 813 ordenaron a los sacerdotes que advirtieran a sus fieles que los encantos no pueden aliviar nada ni a las personas ni a las bestias enfermas o moribundas y que no son más que engaños y ardides del demonio": CAro, Brujas, 88), sino también de muchos que no pertenecían a ella (RobBins, 540b-54la; Thomas, 536). A esta categoría de charlatanes ineptos e ignorantes parece pertenecer el saludador de Flor de santidad, pese a la fe lugareña - "¿Van a ver al saludador?... ¡A mi amo le sanó una vaca! Sabe palabras para deshacer toda clase de brujerías" (Flor, 68 - - y al supuesto conocimiento de un "remedio contra todos los males así de natural como de brujería" (ibid., 60). Aparte de condenarlo los resultados que presenciamos, pesa también sobre él una amenaza de excomunión, con la cual la ley eclesiástica había amenazado ya a todos los brujos blancos desde el año 900 (RoBBINS, $540 b$ ) .

Cuando la avarienta y supersticiosa ventera advierte el mal que diezma su rebaño, sospecha que está embrujado y decide solicitar ayuda al saludador para que diagnostique el daño y lo detenga (cf. Robbins, 335a, y Thomas, 548). Después de alternar cazurramente negativas con intencionados elogios de los animales y de destacar codiciosamente un cordero especial, que se le entrega en pago arries- 
gando el éxito del tratamiento ${ }^{20}$, el saludador desafía a la autoridad eclesiástica proporcionando lo que se le pide:

...benigno y feliz como un abuelo de los tiempos patriarcales, dejó caer una larga bendición sobre el rebaño...:

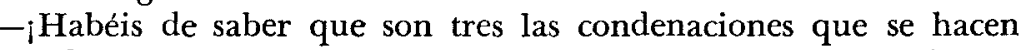
al ganado!... Una en las hierbas, otra en las aguas, otra en el aire... ¡Este ganado vuestro tiene la condenación en las aguas!

La ventera escuchaba al saludador con las manos juntas y los ojos húmedos de religiosa emoción. Sentía pasar sobre su rostro el aliento del prodigio...

- La condenación de las aguas solamente se rompe con la primera luna, a las doce de la noche. Para ello es menester llevar el ganado a que beba en fuente que tenga un roble, y esté en una encrucijada... ...La ventera, con el rostro resplandeciente de fe, cavilaba recordando dónde había una fuente que estuviese en una encrucijada y tuviera un roble, y entonces el saludador le dijo:

-La fuente que buscas está cerca de San Gundián, yendo por el Camino viejo... (Flor, 75-77).

En la prescripción del saludador se destacan cinco elementos importantes: la primera luna, la medianoche, la fuente, el roble y la encrucijada, más uno aparentemente ocasional: la cercanía de San Gundián. Tal reunión se relaciona con antiguos cultos paganos. La patrocinadora de la brujería y de quienes la practicaban fue una triple diosa vinculada con la luna y sus fases -Selene-Hécate-Diana o Luna-Proserpina-Diana-, que era además deidad de las encruci-

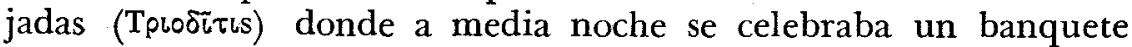
en su honor (Thomas, 47, 48; Hole, 27; Evans-Wentz, 223, 428, 434-435; véase también Posse, 515-516); la luz de la luna, reflejada en una fuente, tenía la virtud de ahuyentar la enfermedad y el sufrimiento hacia la cima de las montañas (Lawson, 165). Esto explica no sólo parte de las indicaciones del saludador, sino también la preocupación de Candelaria en Sonata de otoño:

-iAy!... Llévate esa luz.

${ }_{-}$¿Pero van [a] estar a oscuras? Miren que es malo tomar la luna.

Concha preguntó sonriendo:

- ¿Por qué es malo, Candelaria?

La vieja repuso, bajando la voz:

-Bien lo sabe, señorita... ¡Por las brujas! (Son. ot., 120),

20 Si bien Grillot de Givry dice que, en caso de enfermedad o peste, el brujo proporcionaba el tratamiento a cambio de una retribución razonable (GrILlot, 177), Christina Hole sostiene que esta actitud mercenaria es síntoma de decadencia, pues un pago en dinero podía arriesgar el éxito de una cura; por esto, el brujo blanco sólo recibía un regalo insignificante pasado cierto tiempo (HoLE, 142). 
una alusión en Gerifaltes de antaño:

...De nuevo iba a comenzar la huida, sañuda y rebelde, con el paso a la media noche por las aldeas dormidas al claro lunar que aman las brujas (Gerif., 249),

y el lugar donde se encuentra Mari-Gaila al mudarse el decorado en la escena del Trasgo Cabrío (Div. pal., 185):

... Otra vez se trasmuda el paraje. Hay una iglesia sobre una encrucijada. Las brujas danzan en torno. Por la puerta sale un resplandor rojizo... El Cabrio sobre la veleta del campanario, lanza su relincho,

el cual contribuye a encadenar lo anterior con los elementos restantes. Pertenecen éstos a un culto quizá más antiguo: el de los árboles - particularmente robles donde influyeron los celtas- y de las fuentes (Rodríguez, 95-101; Posse, 508-511), que solían encontrarse en las encrucijadas. La Iglesia, que condenó las persistentes supersticiones originadas en el culto a la luna (Concilio de Compostela, 1056) (RodRíguez, 39), intentó desarraigar también el de los árboles y las fuentes, como lo demuestran las prohibiciones emanadas de los Concilios de Arles (452), de Tours (567), de los toledanos XII y XIII y de los de Braga (Portugal) (ibid., 37, 39), a las que deben agregarse las contenidas en el Edicto de Carlomagno. El resultado fue vano y se terminó por disfrazar el viejo culto asociándolo con imágenes cristianas o levantando en las proximidades santuarios o edificios consagrados, de los cuales son ejemplo Nuestra Señora del Roble tanto en Anjou como en Maine (Evans-Wentz, 434-435) y el convento de Gondarín del que se ocupó Valle-Inclán en un artículo primerizo (Public., 60-63) . La Iglesia, sin embargo, lo recordó cuando le convino, como en el juicio contra Juana de Arco, acusada de haber frecuentado un viejo roble y la fuente que estaba al pie ${ }^{21}$; mejor suerte y más larga vida tuvieron las brujas gallegas que se reunían en torno a otra en el arenal de Coiro (Rodríguez, 44). Las fuentes paganas pasaron a ser pozos santos, donde, tanto en Grecia como en Flor de santidad, acuden a beber los enfermos de mal de ojo (LAwson, 14). El remedio del viejo y católico saludador merecería comentario semejante al que Christina Hole dedica a sus compatriotas de otras épocas: "...hubo quienes se dedicaban... a la magia durante la semana e iban a la iglesia el domingo... o quienes conjuntamente usaban elementos paganos y sagrados para sus sortilegios, y curaban con un antiguo cantarcillo que reunía en un solo verso el nombre de Cristo y el del nórdico dios Baldur" (Hole, 112-113).

21 Sir WALTer ScotT, Letters on demonology and witchcraft, The Citadel Press, New York, 1970, 164. 
Base de muchas curaciones realizadas por los saludadores es la magia natural procedente del conocimiento de distintas hierbas ${ }^{22}$ :

...Adega arreó sus ovejas, y... las llevó a que bebiesen en la fuente del atrio... el estremecimiento del negro follaje... uníase al murmullo de la fuente milagrosa... donde una mendiga sabia y curandera ponía a serenar el hinojo tierno con la malva de olor (Flor, 106),

breve cuadro que se repetirá con un rasgo nuevo en "Flor de la tarde" (Aromas, 42):

En el oloroso atrio de la ermita

La fontana late como un corazón, Y pone en el agua yerbas olorosas, Una curandera murmurando prosas Que rezo y conjuro juntamente son,

y en ambos textos advertimos que el agua de las fuentes paganocristianas no sólo ejercía su poder por contacto directo sino también indirecto. Según el saber popular, "no hay mal en el mundo que no tenga su medicina en una yerba" (Aguila, 107), incluso los más desesperados; pero su virtud debe ser acompañada por la seriedad de la fe:

... [la inocente] parecía una sombra milenaria... En la mano traía un manojo de hierbas. Me las entregó con un gesto de sibila, y murmuró en voz baja:

- Cuando se halle con la señora, mi Condesa, póngale, sin que ella lo vea, estas hierbas bajo la almohada. Con ellas sanará...

Yo sentí, como un vuelo sombrío, pasar sobre mi alma la superstición, y tomé en silencio aquel manojo de hierbas mojadas por la lluvia. Las hierbas olorosas, Ilenas de santidad, las que curan la saudade de las almas y los males de los rebaños, las que aumentan las virtudes familiares y las cosechas... iQué poco tardaron en florecer sobre la sepultura de Concha...! (Son. ot., 32-34).

22 Evans-Wentz, 174, recoge un episodio según el cual una bruja de Cornwall, después de pronunciar un ensalmo en el dialecto de la región, dio a un granjero unas hierbas para sus caballos, que estaban muriéndose de una enfermedad desconocida; aplicado el remedio, la peste cesó, pues las hierbas habian ahuyentado todos los malos espíritus del establo. Jules Michelet, Satanism and witchcraft. A study on medieval superstition, transl. by A. R. Allison, The Citadel Press, New York, 1960, p. 81, afirma que lo más seguro que conocemos acerca de los métodos de las brujas es el uso frecuente que hacían para los más variados propósitos de hierbas de dudosa reputación y peligrosas propiedades pero que resultaban salutíferas, fuera como calmantes o como estimulantes, para sus enfermos. 
... Cerca de la cama... estaba mi capote de cazador,... y esparcidas encima aquellas hierbas de virtud oculta, solamente conocida por la pobre loca del molino. Me levanté en silencio, y fui por ellas. Con un extraño sentimiento, mezcla de superstición y de ironía, escondí el místico manojo entre las almohadas de Concha (ibid., 75) .

Si anulado por la ironía descreída el poder de las hierbas ha sido centro de una melancólica evocación, lo es también de una escena sutil e intencionadamente cómica, donde lo evocado será su empleo maléfico (Marquesa, 159) :

Colombina: ¿Cuál es tu delito? ¿De qué eres culpado? Arlequin: TTal vez de hechicero! Colombina: ¡Te darán tormento! Por un bebedizo de yerbas donceles, Cuentan que una bella me dio sus anillos, Áureas filigranas, labrados joyeles, Claras pedrerías, galanes cintillos.

A diferencia del sistema terapéutico a base de hierbas, el procedimiento de curar con palabras, al que se alude en Cara de Plata (31) y en Flor de santidad (68), es puramenté mágico -si aceptamos que la sugestión pertenece a esa categoría- y su eficacia depende del poder de convicción de quien lo aplica y/o de la crédula voluntad de aceptar de quien recibe el tratamiento ${ }^{23}$. Nada tiene de extraño, entonces, el efecto causado por una lengua incomprensible pero religiosamente prestigiosa sobre una multitud exaltada, como ocurre en Divinas palabras (284-285).

Cuando de una manera u otra alguien o algo ha sido perjudicado por maleficios, una de las precauciones urgentes consiste en buscar al causante por medios tan mágicos como el daño mismo (Flor, 114-115):

-Yo tuve un amo a quien le embrujaron todo un rebaño.

El hijo de la ventera, que estaba echado sobre un arcón en el fondo de la cocina, se incorporó lentamente:

$-¿ Y$ tu amo qué hizo?

${ }^{23}$ Sólo puedo ilustrar el caso con una anécdota. Un pariente mío, estudiante de medicina y practicante en un hospital de provincia, tuvo que enfrentarse con una muela en tal estado que sus conocimientos y habilidad no podían tratarla. Quizá encomendándose a Esculapio, miró muy serio al paciente y le dijo: "Te voy a curar de palabra", agregando inmediatamente algunos vocablos de repentina invención. El enfermo se fue muy contento y volvió a la semana siguiente para que le aplicara de nuevo el efectivo remedio. Naturalmente, la muela seguía tan mal como antes, pero el dolor desaparecía cada vez que mi pariente pronunciaba las misteriosas palabras. 
-Pues verse con quien se lo tenía embrujado y darle una carga de trigo porque lo libertase. Mi amo no sabía quién fuese, pero una saludadora le dijo que cogiera la res más enferma y la echase viva en una fogata. Aquella alma que primero acudiese al oír los balidos, aquélla era...

- ¿Y acudió?

-Acudió.

El consejo de la saludadora refleja una realidad (". . Otra práctica era quemar... vivo uno de los animales... embrujados... Estos métodos se proponían traer de vuelta al brujo a la escena del crimen", Tномas, 544). El hijo de la ventera sigue la sugerencia del interlocutor, y la casualidad contribuye al efecto (Flor, 118-119) :

...La vieja atizaba el fuego, y con los ojos encendidos vigilaba el camino... De pronto llamó al hijo:

-Mira alli, rapaz.

Y le mostraba una sombra... que parecía haberse detenido a lo lejos. El mozo murmuró:

-Deje que llegue quien sea...

...El peregrino estaba detenido en medio de aquel sendero donde se había mostrado a la pastora por primera vez.

El mozo realiza lo anunciado simbólicamente en una anticipación descriptiva (ibid., 67):

En la paz de una hondonada umbría, dos zagales andan encorvados segando el trébol oloroso y húmedo, y entre el verde de la hierba, las hoces brillan con extraña ferocidad,

y se hace justicia por su propia mano (ibid., 121-122) :

...Una sombra llamaba sigilosa en la venta: La hoz que tenía al hombro brillaba en la noche con extraña ferocidad. De dentro abrieron sin ruido, y hubo un murmullo de voces. Adega las reconoció. El hijo decía:

-Esconda la hoz.

Y la madre:

-Mejor será enterrarla.

El sobreentendido acto de violencia es quizá magnificación de la menos contundente costumbre de arañar al malhechor hasta hacer correr su sangre, con lo cual, se decía, finalizaría el daño (Tномas, $544)$.

Otras soluciones, sin embargo, no necesitan ser tan drásticas, aunque acaso satisfagan menos la contenida furia de los damnificados. Una de ellas es el empleo del circulo del Rey Salomón (Flor, 56, 113; Aguila, 202; Hist., 80, 81; Cruz., 135), que quizá sólo sea esa 
figura ${ }^{24}$, a la cual hubiera quedado reducido el sello -pentagrama o exagrama inscrito en un círculo- o el escudo - pentagrama dentro de la misma figura- (CAvendish, 239, 242, 243; Grillot, 97, 339340; Blavatsky, 303; Budge, 40) y de los cuales se afirma que obran milagros (Budge, 203), alejan a los vampiros (LAwson, l13, n. l) y son salutíferos (BUdGe, 233). Pero según el pensar corriente "más vale prevenir que curar", y a ese fin se aplica la virtud de la higa protectora (Voces, 113; Embruj., xxxix; Corte, 224, 225) que, hecha de azabache, sirve de amuleto (Flor, 20; Cruz., 53; cf. Caro, Mitos, 270) y, en su ausencia, se reemplaza con un muy extraño gesto de la mano (Caro, Mitos, 270; Lawson, 14), descrito por el maestro Gonzalo Correas -"higa es hecha del dedo pulgar metido entre los dos siguientes, el de enseñar y el mayor, cerrado el puño" (apud Caro, Mitos, 275) - y que devuelve con creces el daño a quien lo intenta (LAWSON, 14).

A la magia blanca pertenecen también ciertos procedimientos terapéuticos y preventivos en los cuales intervienen sacramentos, símbolos o palabras pertenecientes a la tradición cristiana y a los que se hace funcionar como sortilegios benéficos. Tal es el caso del bautismo prenatal que presenciamos en Aguila de blasón:

La preñada... descubre el vientre hidrópico... Sabelita traza una cruz sobre aquel vientre fecundo que porta una maldición, ... repite en alta voz las palabras que el abuelo dicta en voz baja: La fórmula sagrada que rompe el hechizo.

Sabelita: Yo te bautizo con el agua santa del Jordán, como al Señor Jesucristo bautizó el Señor San Juan. Yo te bautizo y te pongo el nombre bendito que porta la santidad y la sanidad consigo. Si niña hubieres de nacer, el nombre de la Virgen Santísima habrás de tener, y si de varón hubieres la condición, tendrás el nombre de San Amaro Glorioso, que se sienta a la mesa de Dios Nuestro Señor Todopoderoso. Amén Jesús (Aguila, 207-208).

La escena se inspira en una creencia que todavía sobrevive en zonas rurales y según la cual los niños medran mejor después de bautizados. A su vez, ésta continúa otra de la Edad Media tardía que consideraba esencial el sacramento para la supervivencia física de la criatura y que, ocasionalmente, dio lugar a situaciones como la dramatizada por Valle-Inclán, pues se llegó a administrarlo a la placenta donde nacía envuelto el niño (Thomas, 37). Por otra parte, la preocupación de la familia por atenerse a una serie de exigencias especiales:

24 Cf. Posse, 513: “. . . se habla de una especie de círculo (sobre todo en la zona de Pontevedra) identificado como el símbolo del Rey Salomón”. 
El Abuelo: Perdone, señora, mas habrá de servirnos de madrina en un bautizo. Tengo una hija que no logra familia por mal de ojo que le hicieron siendo moza, y nos han dicho que solamente se rompía el embrujo viniendo a una puente donde hubiese una cruz, y bautizando con el agua del río después de las doce de la noche. Tres días llevamos acudiendo a este paraje, y el primero no pasó nadie que pudiera apadrinar, y el segundo deshizo la virtud un can que venía escapado de la aldea, y que cruzó la puente... Pues sabrá mi señora que para ser roto el embrujo no ha de cruzar la puente, hasta hecho el bautizo, ni can ni gato, ni persona humana..., una saludadora nos dijo que para arredrar al trasgo, y lo mismo a las brujas, en cada cabo de la puente pusiésemos un ochavo moruno de los que tienen el círculo del Rey Salomón (Aguila, 201-202),

recuerda otras semejantes acerca del día en que debe realizarse la ceremonia, el tipo de agua conveniente y los requisitos apropiados de los padrinos (Thomas, 37). A todo ello se agrega la precaución no demasiado eficaz de colocar en lugar estratégico las monedas con el signo curativo-protector.

Cuando Valle retrata a Adega, señala entre las varias muestras de su fetichismo la presencia de "hojas de misal" (Flor, 20), que deben ser los evangelios de los cuales habla Rodríguez López:

. . Llaman así a unos trocitos de papel impreso que contienen algún párrafo o versículo del Evangelio, y que envueltos en tela y metidos en saquitos cerrados..., traen los creyentes cosidos a la ropa interior, con el fin de librarse del mal de ojo o de otros maleficios... aunque otra cosa crean las personas piadosas, está prohibido su uso por los obispos (Rodríguez, 64) .

Del mismo orden, aunque extendidos a otros círculos y favorecidos por la Iglesia, son los escapularios con ensalmos escritos ${ }^{25}$, como el "Detente, bala", al que se alude en un pasaje de Sonata de invierno:

La Reina clavó la aguja en el acerico de damasco rojo..., y sonriendo me mostró el escapulario:

- ¡Ya está! Es un regalo que te hago, Bradomín.

Yo me acerqué para recibirlo de sus manos reales. La Señora, me lo entregó, diciendo:

-iQue aleje siempre de ti las balas enemigas! (Son. inv., 74),

y que se volverá a recordar en "Aires nacionales": "Las comunidades de monjas bordaban escapularios con el detente bala" ${ }^{26}$; su virtud,

25 RoBINs, 86b: "The use of written charms placed in amulets was indeed sanctioned by the Church, and won the approval of Thomas Aquinas".

26 "Aires nacionales", introducción a La corte de los milagros, en El Sol, Madrid, 21 de octubre de 1931, capitulillo X, col. 1. 
sin embargo, de acuerdo con el resultado que tiene en el caso de Bradomín, es tan dudosa como la de los ochavos morunos. No sólo aceptado sino difundido por la Iglesia es el Agnus Dei, al cual se atribuye la salvación de un herido en ;Viva mi dueño! (252); de él dice Rodríguez López que era una imagen del cordero de Dios impresa en cera blanca, la cual, reproducida en limitada cantidad, "bendecía el Papa el año de su elección y después de cada siete años, por cuya circunstancia" las figuritas "eran raras y muy estimadas", pues, por ruego del Pontífice, quienes las usaran "con pureza y devoción" podían confiar en librarse de todo mal: enemigos, peligros, visiones y espantos (RodRíGuez, 185-187) .

Resumen de magia negra y magia blanca y acumulación de objetos paganos y cristianos con los cuales se defiende la gitanería andaluza es el siguiente pasaje de La corte de los milagros:

...Aquel rancho gitano tiene un resalte de ochavo moruno: -Luces cobrizas, magias y sortilegios, ciencia caldea de grimorios y pentáculos-. En Castril de las Cuevas la herradura, el cuerno, el espejillo rajado, los azabaches de las gigas, el santico bendico con ataduras y por los pies ajorcado, son los mejores influjos para torcer y mejorar los destinos del castigado Errate. El cuerno hace mal de ojo a los vellerifes: El espejillo enferma de mưerte a los jueces: El santico ligado y ajorcado, abre las cárceles: La herradura, prospera sobre los caminos y saca adelante en los pasos apurados: Las gigas, mejoran la estrella del nacimiento (Corte, 224-225).

El texto demuestra hasta qué punto la inseguridad de un grupo mantiene vivas tales creencias, pues, viéndose discriminado por las autoridades y carente de toda protección, necesita buscarla espontánea o forzadamente en lo sobrenatural.

\section{Los adoradores del Diablo}

De acuerdo con el concepto tradicional, el Sabbat es la reunión de brujos durante la cual rinden homenaje y culto al Diablo ${ }^{27}$ y se corresponde en español con el demasiado impreciso y general aquelarre. Sus verdaderas características provienen de una combinación de antiguas prácticas y leyendas de hechicería y de ideas he-

27 En realidad, sólo había cuatro Sabbats durante el año, celebrados respectivamente el 2 de febrero, la víspera de mayo, el $1^{\text {o }}$ de agosto y el 31 de octubre por la congregación de brujos en pleno; los Esbats o reuniones semanales de cada conventículo en particular no ocurrían necesariamente en un determinado día de la semana ni siempre en el mismo sitio (Margaret Alice Murray, The god of the witches, Anchor Books A212, Doubleday and Co., Garden City, N. Y., 1960, pp. 67 y 75). 
réticas más recientes; pero existen vehementes posibilidades de que mucho de lo que se le atribuye fuera "fabricado principalmente durante los siglos xiv y $\mathrm{xv}$ por los investigadores y jueces vinculados con la Inquisición... y aceptado definitivamente como aspecto de la brujería europea en el siglo xvi" (RobBins, 414b-415a). Los presuntos adeptos de la religión satánica eran considerados herejes y por esta razón encarnizadamente perseguidos y castigados. Gracias a un temor insuflado desde arriba, estos brujos invadieron la imaginación de la gente con rasgos y peculiaridades sugeridos o forjados en las cámaras de tortura, y terminaron barriendo superficialmente con otros más antiguos y más reales. Éstos perduran todavía; de aquéllos sólo subsiste hoy lo más exterior y pintoresco, y, acaso vagamente, el recuerdo de la herejía que se les atribuyó. A lo último apunta Valle-Inclán, a través de un concepto no imposible, por boca de una indignada Andréiña cuando responde al insulto de Montenegro:

...¡Bruja! Nadie en el mundo me dijo ese texto, que vengo de muy buenos padres, y no habrá cristiano que me haya visto escupir en la puerta de la iglesia, ni hacer los cuernos en la misa mayor (Roman$c e, 122)$.

El sometimiento al Diablo y los conocimientos derivados de la situación permitían a los brujos disfrutar de prerrogativas sobre los demás hombres. Merced al ungüento (RoBbiNs, 364b-366b), aplicado al cuerpo o a la tan mentada escoba, podían, vía chimenea, volar hacia donde se realizaba el aquelarre. Cuando Valle lo recuerda es, sobre todo, en circunstancias que requieren respuestas rápidas y cortantes a un personaje sospechoso de malas artes (Embruj., cxxvi) :

Diana de Sálvora: Venía a vuestra puerta por un puñado de harina leveda para amasar.

Juan de Juno: ¿Para amasar o para un unto?

Diana de Sálvora: ¡Ni que fuera bruja!

La Navora: Bruja no; pero les echas un requiebro.

Unido a la idea del indecente baile celebrado durante el Sabbat (Roвisns, $421 b$ ), al cual alude también Arlequín cuando habla de "la cabriola de una bruja sabática" (Marquesa, 78), aparece en el diálogo entre el Fuso Negro y Pichona la Bisbisera (Cara, 254) :

La voz de la chimenea: ... ISube, Pichona, y echamos un baile! Pichona la Bisbisera: Me falta el unto para los sobacos.

En cuanto al vuelo en sí, cuya primera ilustración conocida se encuentra en Le Champion des dames de Marin le Franc (ca. 1440) 
(RobBins, 30a; cf. 366ab, 418a), es negativamente aplicado a Don Pedro Bolaño por Juana de Juno en su intencionada contestación a Rosa Galans (Embruj., LIv) :

La Galana: ¿Está el amo?

Juana de Juno: Adentro entró, por la puerta no salió, brujo no nació y por la chimenea no voló.

El diálogo de "Ligazón" entre la Raposa y la Ventera lo ofrece a raíz de un semicontenido estallido de rivalidad y tirantez entre ambas mujeres, donde no falta la jactanciosa pretensión del comercio sexual con el Diablo (Retablo, 29-30) :

La Ventera: ¡Comadre, somos de un arte!

La Raposa: ¿Usted es volandista?

La Ventera: A las doce del sábado monto en la escoba, y por los cielos. ¡Arcos de sol! ¡Arcos de luna!

La Raposa: [Está usted amonada!

La Ventera: Amonada porque le saco ventaja.

La Raposa: iA mí todas las noches me visita el Trasgo!

La Ventera: ¡Usted lo sueña!

Tal comercio se volvía promiscuo en uno de los momentos culminantes del Sabbat (RobBins, 423a), como lo señala una descripción de Sonata de estio, inspirada sin duda en Goya: "sus senos negros y colgantes recordaban las orgías de las brujas y los trasgos" (Son. est., 172).

En la simbólica escena del Trasgo Cabrío (Div. pal., 186, 189-190) vuelve a mencionarse el vuelo, pero el vehículo cambia: es el Trasgo mismo quien arrebata con él a la ansiosa mujer del sacristán:

El Cabrio: |Vente conmigo al baile!

Mari-Gaila: De tus romerías saber no quiero.

El Cabrio: iJujurujú! Te llevaré por los aires, más alto que el Sol y la Luna. ¡Jujurujú!...

...Mari-Gaila Gaila se siente llevada en una ráfaga... El impulso acrece, va suspendida en el aire, se remonta y suspira con deleite carnal. Siente bajo las faldas la sacudida de una grupa lanuda, tiende los brazos para no caer, y sus manos encuentran la retorcida cuerna del Cabrio...

Mari-Gaila: ¿Adónde me llevas, negro?

El Cabrio: Vamos al baile.

Todo el pasaje trae a la memoria una ilustración del Compendium maleficarum y lo dicho por su autor: "A veces las brujas eran real- 
mente transportadas por el Diablo bajo el aspecto de un chivo $\mathrm{u}$ otro animal fantástico" (RoBBins, 513b), corolario del préstamo que Santo Tomás de Aquino tomó de Alberto Magno, según quien, antes de tentar a Cristo en la cumbre de la montaña, Satán lo había llevado allí sobre los hombros (ibid., 28b). Intencionadamente ambiguo, por el contrario, resulta el texto de "Mi hermana Antonia" (Cofre, 139-140) :

. .oóa en la casa batir las puertas, y gritar buscando a mi hermana Antonia... Desde la puerta de la catedral una beata la descubrió desmayada en el tejado...,

que nos deja en una duda para cuya solución sólo habría cuatro respuestas posibles pero no probables: vuelo, metamorfosis o proeza bajo influjo hipnótico debidos a los poderes de Máximo Bretal, por un lado, y, por el otro, un caso de sonambulismo, como en la romántica ópera de Bellini.

Valle-Inclán, quien funde en el apellido de Tadea Calderón el recuerdo de un dramaturgo célebre por su tratamiento de la honra y la alusión a un imprescindible utensilio de las brujas, rápidamente alude a dos propiedades de esta condición: la capacidad de pasar por espacios mínimos ${ }^{28}$, de la cual la Dueña supone poseedor a $\mathrm{Ar}$ lequín (Marquesa, 165-166) :

La Dueña: ¿Pues no estaba en prisión por hechicero?

Dorotea: ¡El diablo debe ser en su figura, o le dejó escapar el carcelero!

La Dueña: A fuer de mago con sus artes pudo salir por un resquicio del postigo,

y la capacidad de hacerse invisible, atribuida a Máximo Bretal: "De pronto, aquella tarde, estando mirándolo, desapareció" (Cofre, 108) ${ }^{29}$. Esta última se relaciona inmediatamente con la de metamorfosearse, pues lo veremos primero bajo el aspecto de un fraile franciscano cuando intenta convencer a la madre de Antonia y luego bajo el de gato negro, visible unas veces e invisible otras, durante la realización de su venganza (Cofre, 115, 121, 122-123, 128-130) ${ }^{30}$. Tal

28 Según Guazzo, los brujos podían transformarse en animales pequeños y escurrirse por agujeros imperceptibles (RoBbins, 344ab).

${ }^{29}$ Con cierto sesgo burlón, Valle alude a ello en La lámpara maravillosa: “... cai en la tentación de practicar las ciencias ocultas... aun cuando no hallé en las artes mágicas el filtro con que hacerme invisible" (Lámp., 178-179).

30 El tema del gato atormentador volverá en "La rosa de papel" (Retablo, 71) con el delirio de la Encamada y en un contexto muy diferente. Allí acaso sea símbolo de la preocupación de la enferma acerca del destino que su marido dará al dinero tan duramente ahorrado por ella, según se desprende de la pregunta de una vecina: "¿Luego es verdad que la difunta deja un gato de dos mil pesos?” (ibid., 99) 
mutación está registrada en casi todos los libros que se ocupan de brujería. Según Grillot de Givry, los gatos negros desempeñaron en ella un importante papel y se los consideraba brujas transformadas, lo cual explicaría las masacres que de ellos hicieron hasta no hace mucho los campesinos europeos (GRILlot, 136). Fueron causa, además, de un cargo recurrente en los juicios, como en el de Anne Bodenham, ahorcada en Salisbury (1653), sobre quien pesaba la acusación de haberse cambiado en gato negro para inducir a Ann Styles al servicio del Diablo (RobBins, 140a), o como en el de la Madre Samuel, ejecutada en 1553, de quien se dijo había maldecido a Lady Cromwell y provocado en sus sueños el ataque de un gato, de cuyas resultas la dama enfermó y murió al poco tiempo (HoLE, 50), hecho que tanto recuerda varios detalles de "Mi hermana Antonia".

También El embrujado acoge la metamorfosis, pero la aprovecha más ampliamente. En respuesta a la jactanciosa seguridad del $\mathrm{Pa}$ jarito, quien no teme los supuestos embrujos de Rosa Galans en los que sólo reconoce el atractivo de "sus buenos colores, y el andar garboso, y el aire del refajo, y el pico" (Embruj., xci-xcII), Anxelo cuenta su propia historia:

Volviendo de la siega, ya puesto el sol, salióme al camino un can ladrando, los ojos en lumbre. Le di con el zueco y escapó dando un alarido que llenó la oscuridad de la noche como la voz de una mujer cautiva. A poco de andar descubro un ventorrillo, y a ella sentada en la puerta. Entré para recobrarme... iNunca entrara! Por su mano me llena un vaso. Lo bebo, y al beberlo siento sus ojos fijos. Lo poso, y al posarlo reparo que a raíz del cabello le corre una gota de sangre. Recelándome, le digo: Tienes sangre en la frente. Ella toma un paño, se lo pasa por la cara y me lo muestra blanco. Luego salta a decirme: ¿Tú vienes por el camino del río? .. ¿A quién topaste en el camino? $\mathrm{Y}$ en aquel momento, yo reconozco en su voz el alarido del perro al darle en la cabeza la zocada. ¡Ya no pude salir de su rueda! Sin apartarme los ojos, se pone a decir que precisa un criado... Ella, riendo, me dio con el paño que se había pasado por la cara, y en un lóstrego se me aparece cubierto de sangre (Embruj., xCII-XcIv).

Además de la habilidad para preparar bebedizos que dobleguen la voluntad de los hombres, la Galana goza de la capacidad de transformarse, concedida por el Diablo a sus servidores más devotos y competentes (RobBins, 344b; Grillot, 68). Gracias a ella, adquiere el aspecto de un perro, uno de los animales que, según Apuleyo, servía de disfraz a las brujas de Tesalia para realizar sus fechorías (CARo, Mitos, 212). A ello se agrega la herida que, recibida por la bestia ocultadora, afecta también al brujo que la reviste, como ase- 
guran Gervasio de Tilbury y el Malleus maleficarum (Hole, 72) ${ }^{31}$, y que con mayor efectismo sufre el estudiante de Bretal:

...apenas puse la cruz, mi madre empezó a retorcerse, y un gato negro escapó de entre las ropas hacia la puerta. Cerré los ojos, y... oí las tijeras de Basilisa. Después... a la luz de las velas, [el sastre] enseñaba dos recortes negros que le manchaban las manos de sangre, y decía que eran las orejas del gato (Cofre, 129-130).

...cuando partíamos, se apareció en el atrio... el estudiante de Bretal. Llevaba a la cara una venda negra, y bajo ella creí ver el recorte sangriento de las orejas rebanadas a cercén (ibid., 140).

Pero antes del relato de Anxelo, el modo de caminar de la Galana había sugerido a Malvín un comentario y a un viejo el revelar su convicción sobre la doble y maligna naturaleza de Rosa (Embruj., LXII-LXIII) :

Una vieja: ¡Qué andar de malterciar!

Malvin: iQué andar de perra ladronera!

El más viejo de los foráneos: No sabes mozo cuánta verdad hay en esa que hablas a modo de ventolera. Es monstruo, y como tal desenvuelve una parte de bestia. Murió poco ha quien con esa mujer cazó en el monte y pieza cobró.

Con esto se anticipa lo que se desarrollará después y que culminará con la muda escena final, inspirada acaso en La transformación de las brujas de Goya (GriLlot, 69). La mímica indicada en la apostilla describe la modificáción maléfica del gesto defensivo de hacer los cuernos ${ }^{32}$ y nos obliga a presenciar inmediatamente la metamorfosis tanto de la bruja como de quienes sufren su dominio, lo cual añade a sus ya poderosas artes la de convertir a los hombres en bestias (HoLE, 17):

Anxelo y Mauriña salen delante, humilladas las frentes, con un tremido trágico bajo sus harapos. La mirada dura y negra de Rosa Galans los sigue hasta que pasan el vano del arco. La Galana, en el umbral, se vuelve, escupe en las losas y hace los cuernos con la mano izquierda. Las gentes de la cocina se santiguan. Un momento después tres perros blancos ladran en la puerta (Embruj., CXLVII).

La segunda parte de la escena inicial de Romance de lobos combina dos elementos interesantes (Romance, 18-19):

31 Cf. también María Rosa Lida, El cuento popular hispanoamericano y la literatura, Facultad de Filosofía y Letras de la Universidad de Buenos Aires, Instituto de Cultura Latino-Americana, Buenos Aires, 1941, p. 25, y Robbins, $326 b$.

32 Quizá es el mismo gesto presentado por "Asterisco": "la mano suspensa para obrar el mal, / con su circunflejo invoca a Belial" (Pasaj., 84). 
... a la orilla de un rio... las brujas departen sentadas en rueda. Por la otra orilla va un entierro. Canta un gallo.

Las Brujas: ¡Cantó el gallo blanco, pico al canto!

...Las Brujas comienzan a levantar un puente... Canta otro gallo... Las Brujas: „Canta el gallo pinto, ande el pico!

$A$ través de una humareda espesa los arcos del puente comienzan a surgir en la noche... Ya sólo falta colocar una piedra, y las brujas se apresuran, porque se acerca el dia... Canta otro gallo.

Las Brujas: ¡Canta el gallo negro, pico quedo!

El corro de brujas deja caer en el fondo de la corriente la piedra que todas en un remolino llevaban por el aire, y huyen convertidas en murciélagos.

Al construir el fantástico puente las servidoras del Demonio cumplen con un trabajo que éste solía realizar en persona cuando nadie más podía terminarlo, por lo cual muchas de tales estructuras llevan su nombre tanto en Inglaterra como en España (GRILlot, 150); en este caso particular, sin embargo, la obra nocturna quizá sea evocación del puente que debían atravesar los muertos en el viaje al otro mundo ${ }^{33}$. El canto de los dos primeros gallos ritma la prisa con que se le construye y el del tercero pone fin a la presencia de las brujas porque, según la tradición griega al menos, sólo la voz del gallo negro era lo bastante poderosa para disolver'sus reuniones y ahuyentar a todos los malignos visitantes de la noche (LAwson, 137, n. 1, y 195). Con su canto, pues, concluiremos la recorrida por la zona más rica y variada del ocultismo en Valle-Inclán.

Wheaton College,

Emma Susana Speratti-Piñero

Norton, Massachusetts.

\section{ABREVIATURAS}

\section{OBRAS DE VALLE-INCLÁN}

Aguila = Águila de blasón, Imprenta de Sáez Hermanos, 1922 (Opera omnia, XIV).

Aromas $=$ Aromas de leyenda, Villavicencio Editor, Madrid, 1907.

Cara = Cara de Plata, Imprenta Cervantina, Madrid, 1923 (Opera omnia, XIII).

33 Howard Rollin Patch, El otro mundo en la literatura medieval, Fondo de Cultura Económica, México, 1956, pp. 17-18, 43, 60, 69, 75, 91, etc.; Hilda Roderick Ellis, The road to Hell. A study of the conception of the dead in Old Norse literature, Cambridge University Press, London, 1943, pp. 173, 186, $189,190,191$. 
Cofre $=$ Cofre de sándalo, Librería General de Victoriano Suárez, Madrid, 1909.

Corte $=$ La corte de los milagros, Imprenta Rivadeneira, Madrid, 1927 (Opera omnia, XXI).

Cruz. = Los cruzados de la causa, Tipográfica Europa, Madrid, 1920 (Opera omnia, XXII).

Cuernos $=$ Los cuernos de Don Friolera, Imprenta Cervantina, Madrid, 1925 (Opera omnia, XVII).

Div. pal. = Divinas palabras, Imprenta Yagües, Madrid, 1920 (Opera omnia, $\mathrm{XVII)}$.

Embruj. = El embrujado, Imprenta de José Izquierdo, Madrid, 1913 (Opera omnia, IV).

Enam. = Farsa de la Enamorada del Rey, Sociedad General Española de Librería, Gráfica Ambos Mundos, Madrid, 1920.

Flor $=$ Flor de santidad, Imprenta Helénica, Madrid, 1920 (Opera omnia, II).

Gerif. = Gerifaltes de antaño, Imprenta de Primitivo Fernández, Madrid, 1909.

Hist. = Historias perversas, Casa Editorial Maucci, Barcelona, [1907].

Jard. nov. = Jardin novelesco, Tipografía de la Revista de Archivos, Bibliotecas y Museos, Madrid, 1905.

Jardin $u m b .=$ Jardin umbrio, Imprenta de José Izquierdo, Madrid, 1914 (Opera omnia, XII).

Lámp. = La lámpara maravillosa, Artes de la Ilustración, Madrid, 1922 (Opera omnia, I) .

Marquesa = La Marquesa Rosalinda, Imprenta Cervantina, Madrid, 1924 (Opera omnia, III).

Martes $=$ Martes de Carnaval, Imprenta Rivadeneira, Madrid, 1930 (Opera omnia, XVII).

Pasaj. = El pasajero, Sociedad General Española de Librería, Diarios, Revistas y Publicaciones, S. A., Imprenta Yagües, Madrid, 1920.

Pipa = La pipa de kif, Sociedad General Española de Librería, Madrid, 1919.

Public. = Publicaciones periodisticas de don Ramón del Valle-Inclán anteriores a 1895, edición, estudio preliminar y notas de William L. Fichter, presentación de Alfonso Reyes, El Colegio de México, México, 1952.

Respl. $=$ El resplandor de la hoguera, Imprenta de Primitivo Fernández, Madrid, 1909.

Retablo = Retablo de la avaricia, la lujuria y la muerte, Imprenta Rivadeneira, Madrid, 1927 (Opera omnia, IV).

Romance $=$ Romance de lobos, Imprenta de José Izquierdo, 1914 (Opera omnia, XV).

Son. est. = Sonata de estio, Imprenta de Antonio Marzo, Madrid, 1903.

Son. inv. = Sonata de invierno, Tipografía de la Revista de Archivos, Bibliotecas y Museos, Madrid, 1905.

Son. ot. = Sonata de otoño, Tipografía de la Revista de Archivos, Bibliotecas y Museos, Madrid, 1905.

Son. prim. = Sonata de primavera, Imprenta Helénica, Madrid, 1917 (Opera omnia, V).

Tirano $=$ Tirano Banderas, Imprenta Rivadeneira, Madrid, 1926 (Opera omnia, XVI).

Viva $=$ ¡Viva mi dueño!, Imprenta Rivadeneira, Madrid, 1928 (Opera omnia, $\mathrm{XXII)}$.

Voces $=$ Voces de gesta, Imprenta Alemana, Madrid, 1912. 


\section{OBRAS DE CONSULTA}

Blavatsky = Helena P. Blavatsky, The theosophical glossary, The Theosophical Publishing Society, London, 1892.

Budge $=$ Sir E. A. Wallis Budge, Amulets and talismans, University Books, New Hyde Park, N. Y., 1968.

Caro, Brujas = Julio Caro Baroja, Las brujas y su mundo, Revista de Occidente, Madrid, 1961.

Caro, Mitos = Julio Garo Baroja, Algunos mitos españoles y otros ensayos, $2^{4}$ ed., Editora Nacional, Madrid, 1944.

Cavendish $=$ Richard Cavendish, The black arts, G. P. Putnam's Sons, New York, 1967.

Evans-Wentz $=$ W. Y. Evans-Wentz, The fairy-faith in Celtic countries, University Books, New Hyde Park, N. Y., 1966.

Grillot = ÉMILE Grilior DE GIVRY, Picture museum of sorcery, magic and alchemy, transl. by J. Courtenay Locke, University Books, New Hyde Park, N. Y., 1963.

Haining = Peter Haining, The Warlock's Book. Secrets of black magic from ancient grimoires, University Books, New Hyde Park, N. Y., 1971.

Hole = Christina Hole, Witchcraft in England, B. T. Batsford Ltd., London, 1947.

LAwson $=$ JoHn CuthBert LAwson, Modern Greek folklore and ancient Greek religion, University Books, New Hyde Park, N. Y., 1964.

Leland = Charles Godfrey Leland, Etruscan magic and occult remedies, University Books, New Hyde Park, N. Y., 1963.

Lethbridge = T. C. Lethbridge, Witches, The Citadel Press, New York, 1962.

Posse = Rita Posse, "Notas sobre el folklore gallego en Valle Inclán", $\mathrm{CuH}$, 67 (1966), 493-520.

RobBins = Rossell Hope. RobBins, The encyclopedia of witchcraft and demonology, Spring Books, New York, 1968.

Rodríguez = Jesús Rodríguez López, Supersticiones de Galicia y preocupaciones vulgares, Editorial Nova, Buenos Aires, 1943.

SPEnce = Lewis SPEnce, An encyclopaedia of occultism, University Books, New Hyde Park, N. Y., 1960.

Thomas = KeIth Thomas, Religion and the decline of magic, Charles Scribner's Sons, New York, 1971. 